\section{Biomedical Science}

Chang, T.-J. 135

Chen, H.-C. 74, 86, 93

Chen, J.-Y. 141

Chi, C.-W. 101, 141

Chiou, J.-Y. 120

Cho, W.-L. 120, 135

Chou, C.-K. 127, 135

Chou, C.-M. 127

Fann, M.-J. 111

Garcia, R. 79

Hayman, M.J. 93

He, F. 93
Hsu, L.-S. 141

Huang, A.-M. 135

Huang, C.-J. 101, 128

Huang, S.-J. 120

Huang, S.-T. 120

Jove, R. 79

Kung, H.-J. 74, 86, 93, 101

Lee, C.-H. 141

Leu, J.-H. 127

Li, D. 93

Lin, J.-S. 101

Lin, S.-D. 111
Lin, W.-C. 93, 101, 127

Lu, C.-W. 101

Robinson, D. 74, 86, 93, 101

Su, T.-L. 127

Tsou, A.-P. 141

Wang, J.Y.J. 73

Whang-Peng, J.J.K. 101

Wu, C.W. 101

Wu, P.-F. 101

Yang, W.-K. 101

Yustein, J.T. 93

Subject Index Vol. 5, No. 2, 1998

Aedes aegypti 120

$\mathrm{Ca}^{2+} /$ calmodulin-dependent protein kinase 141

CDK 86

Cell growth 79

Cerebral cortex 111

Chromosomal location 141

Cloning 141

Degenerate primers 74

Differential display 74

erbB 93

ERK 86

Erythroleukemia 93

EST database 86

FGF receptor 111

Gastric cancer 101
Genomic DNA 127

Hippocampus 111

Human CaMKK 141

- liver cancer 135

Insect immunity 120

KFC 93

Kinase display 74

Mosquito 120

Oncogenes 79

PKA 86

PKC 86

Polymerase chain reaction 127

Protein kinase 86, 135

- serine/threonine kinase 101, 127

- tyrosine kinase 101, 127

RT-PCR 74, 93, 101 sea 93

Serine kinases 74

Serine/threonine kinase 111,120

Signal transduction 79

STAT 79

STE-20 86, 93

Sympathetic neurons 111

TGF $\alpha 93$

Tissue expression 141

Tousled gene 135

Transformation 79

Tumorigenesis 79

Tyrosine kinase(s) 74, 79, 111, 120

YAK 86 